\title{
EDITORIAL Édouard Glissant Chez Non Plus
}

Entre os periódicos brasileiros, a revista Non Plus se destaca pelo fato de acolher - fato inédito até então - um dossiê consagrado ao escritor, poeta e estudioso da poética martiniquense Édouard Glissant (1928-2011). É a primeira vez, com efeito, que um periódico abre espaço para estudos sobre suas obras. Singularmente, a vertente selecionada aqui remete aos estudos conceituais, poético-filosóficos e políticos que desembocam na poética da Relação, isto é, numa linguagem sobre o mundo que faz entender uma linguagem do mundo. Édouard Glissant desenvolveu essa tônica ao longo de oito ensaios distribuídos no período que vai de 1956 a 2009. Publicou no mesmo período dez ensaios onde vários temas - política, história, línguas -, estudados e entendidos através do prisma dessa linguagem sobre o mundo.

$\mathrm{O}$ conjunto das contribuições se divide em duas vertentes. A primeira vertente reúne três estudos que dialogam diretamente com o pensamento do ensaísta. Assim, em "O Diverso como fundamento da(s) poética(s) de Édouard Glissant”, Andrei Ferreira Lima procura mostrar como se articulam os conceitos-chave de Diverso e Relação, a partir dos quais se articulam, à maneira do rizoma, outras "instâncias" da poética glissantiana. Os dois estudos seguintes desenvolvem, de maneira mais detalhada, certas instâncias abordadas no estudo de Ferreira Lima. Uma delas é a língua na sua relação com a identidade. Tal é o intuito da análise "Língua e identidade: tensões”, de Cássio Aguiar. O autor retraça as várias características de interdependência entre línguas e identidades ao entrelaçar a ótica sociológica da identidade (Z. Bauman), com o exame dos (des)equilíbrios das línguas no mundo de hoje (Louis-Jean Calvet) e, finalmente, a visão crítica e poética de Édouard Glissant, em L'Imaginaire des langues. Nabil Boudraa fecha a primeira vertente do dossiê ao tratar de um tema ainda pouco discutido e muito instigante: a paisagem. A paisagem é um livro de história aberto, e que pede para ser 
lido. Em "La poétique du paysage chez Édouard Glissant", Boudraa mostra como Glissant atribui essa função à paisagem, a partir do romance La Lézarde (1958) para, depois, seguir nos estudos do ensaísta os caminhos pelos quais o tema da paisagem se conjuga com a poética da Relação.

A segunda vertente do dossiê se caracteriza por dois estudos que fazem dialogar o pensamento glissantiano com outros universos de intervenção sobre o mundo. Em "O político e o poético em Albert Camus e Édouard Glissant", Raphael Luiz de Araújo visa mostrar os laços, poéticos e políticos, que unem Édouard Glissant a Albert Camus (1913-1960), sobretudo nas suas Crônicas argelinas. Como veremos, ambos compartilham uma mesma "concepção a respeito da função do artista ante os conflitos do mundo". Por sua vez, Naná DeLuca, em "Em vias de existir: uma leitura de Le corps lesbien, de Monique Wittig”, estabelece similitudes entre os mundos e os lugares distantes de Édouard Glissant e da escritora, teórica e lésbica Monique Wittig (1935-2003). Nomear, existir (nos termos de É. Glissant): ambos objetivam nomear, para fazer existir sujeitos invisíveis e/ou silenciados. Para tanto, não basta se apoderar do conteúdo. Por isso, DeLuca mostra como cada qual defende, na sua escritura, a mistura dos gêneros literários e a ultrapassagem dos gêneros tout court, em si só, para abrir para a Relação.

Esperamos que este dossiê sobre Édouard Glissant, pela sua contribuição instigante, marque o início a uma pesquisa rizomática, apta a congregar e tecer análises e leituras em Relação!

Para além das contribuições em torno da poética de Glissant, este nono número da Revista Non Plus também traz à luz cinco interessantes artigos em torno dos estudos literários, além de um estudo de tradução e outro de língua francesa.

Ainda no campo da literatura de expressão francesa, Messan Tossa nos traz uma interessante reflexão sobre a triste figura da criança-soldado, no estudo "La fonction de l'escapisme dans Allah n'est pas oblige d'Ahmadou Kourouma”. Personagem típica do romance de guerra, a criança-soldado reflete o real circundante terceiro-mundista habilmente recriado pelo escritor costa-marfinense Ahmadou Kourouma. Em seguida, em "Rester vivant, de Michel Houellebecq: uma atualização do Poeta maldito", também nos limites do contemporâneo, Augusto Darde investiga como se opera a releitura de Michel Houellebecq da figura oitocentista do poète maudit verlainiano, que, para o Darde, remonta a textos ainda mais antigos constituindo um discurso tradicional da literatura. A partir disso, procura mostrar como o Houellebecq dialoga com esta tradição.

Recuando no tempo, do contemporâneo em direção ao moderno, também em uma perspectiva comparatista, o artigo "A feminilidade de Emma Roualt", de Renan Salmistraro Correio, a partir do livro Le Deuxième sexe, de Simone de Beauvoir (1908-1986), propõe uma releitura de Madame Bovary, sob a perspectiva do feminino, contrapondo analises bastante antigas e consagradas como o ensaio que Charles Baudelaire (1821-1867) dedicou ao livro em 1857 e o ensaio de Gérard Genette, que apontam uma supremacia da masculinidade na obra flaubertiana. 
Já Rafael Souza Barbosa, em seu artigo "Chateaubriand, leitor de Camões: o poeta português nas Mémoires d'outre-tombe", igualmente em uma perspectiva comparatista, analisa a presença do poeta épico português Luís de Camões (c. 1525-1580?), em obras de François-Réné de Chateaubriand (1768-1848), Le Génie du Christianisme (1801) e, sobretudo, Les Mémoires d'Outre-Tombe (1849-1850), onde é mencionado explicitamente.

Complementando as contribuições dedicadas aos estudos literários, Jaqueline Sinderski e Diego Moreira partem de um poema de La Harpe (Ode - 1789) para perscrutar não só as variações atribuídas a essa categoria de poema lírico, mas sobretudo a figura da Rainha Maria Antonieta - talvez a mulher mais vilipendiada da História, a levar-se em conta a obra de Évelyne Lever. Sinderski e Moreira também introduzem o leitor no universo dos libelos, panfletos clandestinos e os chamados gazetiers frondeurs, plenos de pornografia política que pululavam às vésperas da Revolução, traçando, assim, um panorama de como se forjava a opinião pública.

Dedicado aos estudos Tradutológicos, Sheila Maria dos Santos reflete sobre o status do escritor-tradutor escapando da visão tradicional do ofício, enquanto ato puramente mecânico na reprodução linguístico-textual, e adentrando a criação, qual seja, o ato criativo do tradutor. Para isso discorre sobre questões polêmicas dentro dos estudos tradutológicos, como os conceitos de equivalência e fidelidade, além de pensar sobre a noção de autor e de obra. Ao exemplificar suas considerações, apresenta trechos de À la Recherche du Temps Perdu de Marcel Proust, traduzidos por Mario Quintana.

Trazemos ainda a contribuição de Janaína Nazzari Gomes, cujo artigo trata do erro na expressão em língua estrangeira. A autora propõe uma reflexão sobre o erro com base nas considerações de Ferdinand de Saussure, o que, de certo modo, mostra a vitalidade da obra saussuriana. Partindo das noções de parole e langue, Nazzari Gomes elabora considerações que têm no mecanismo analógico e no princípio do arbitrário como signo os principais mecanismos linguísticos presentes na apropriação de uma língua estrangeira, possibilitando, assim, refletir sobre o que convencionalmente chamamos "erro".

Por fim, gostaríamos de anunciar que a partir desde número, a Revista Non Plus deixa de ser a revista dos alunos da área de francês da Universidade de São Paulo, para se tornar a Revista do Programa de Estudos Linguísticos, Literários e Tradutológicos em Francês da Universidade de São Paulo (USP), mudança de estatuto que muito alegra nossa equipe e que, esperamos, trará mais visibilidade para nossa publicação.

Com nossos votos de uma excelente leitura a todos,

Bruno Anselmi Matangrano Dirceu Magri Véronique Dahlet Editores do número 9 